\title{
Morris GROSSMAN, Art and Morality: Essays in the Spirit of George Santayana
}

Edited by Martin A. Coleman. New York, Fordham University Press, 2014, 336 pages

Glen Tiller

\section{(2) OpenEdition}

1 Journals

Electronic version

URL: http://journals.openedition.org/ejpap/364

DOI: 10.4000/ejpap.364

ISSN: 2036-4091

Publisher

Associazione Pragma

Electronic reference

Glen Tiller, "Morris grossman, Art and Morality: Essays in the Spirit of George Santayana », European Journal of Pragmatism and American Philosophy [Online], VII-1 | 2015, Online since 07 July 2015, connection on 23 September 2020. URL : http://journals.openedition.org/ejpap/364 ; DOI : https:// doi.org/10.4000/ejpap.364

This text was automatically generated on 23 September 2020 .

\section{cc) (i) $\Theta$}

Author retains copyright and grants the European Journal of Pragmatism and American Philosophy right of first publication with the work simultaneously licensed under a Creative Commons AttributionNonCommercial-NoDerivatives 4.0 International License. 


\title{
Morris GROSSMAN, Art and Morality: Essays in the Spirit of George Santayana
}

Edited by Martin A. Coleman. New York, Fordham University Press, 2014, 336 pages

\author{
Glen Tiller
}

\section{REFERENCES}

Morris Grossman, Art and Morality: Essays in the Spirit of George Santayana, edited by Martin A. Coleman, New York, Fordham University Press, 2014, 336 p.

1 Morris Grossman, who died in 2012 at the age of 90, was a rare combination of philosopher, musician, and composer. Inspired by American philosophy, especially the philosophy of Santayana, he wrote with originality and verve on a variety of topics. As is befitting a student of Santayana, his thought moves freely over the worlds of philosophy, art, music, literature, politics, and religion. The essays in Art and Morality: Essays in the Spirit of George Santayana, finely edited by Martin Coleman, examine the many moral and conceptual connections amongst these worlds.

2 Grossman proposes a central thesis running through his essays. In the Introduction he tells us: "The intrigue of the art/morality distinction has occurred to me in various, sometimes strange and trivial, ways" (2). He then offers several examples to illustrate what he means by this distinction. In one example, whilst watching C-SPAN, a television channel that broadcasts live feeds from the U.S. Senate, Grossman is struck by the contrast between the mundane but morally significant motions of government officials (e.g. calling for quorum) and the classical music added by the cable channel. The transporting music of Mozart is suddenly the soundtrack for the dutifully working officials and bureaucrats. For Grossman, this "juxtaposition is aesthetically and morally provocative," a "double attentiveness" that he finds pervasive in our life and thought (2). It is such brief, sublime moments of consciousness - or in Santayana's terms, 
'moments of spirit' - that Grossman calls to our attention. He writes with a sense of urgency uncharacteristic in contemporary philosophy.

In life, [he tells us], the choice that [the art/morality] experience embodies and dramatizes is a relationship that is always with us. Even right now. Especially right now. Always right now... [since] any experience at any time has equivalent and searchable parts or moments. (3)

3 However he is not only interested in contrasting moments of moral 'doing' with those of spiritual 'feeling.' He is also keen to stress the higher-order conception of the juxtaposition itself. For the mental act of raising the juxtaposition of doing and feeling to a level of conscious awareness is itself morally and spiritually significant. Referring to the C-SPAN example, he writes: "The juxtaposition created by the quorum call involves us in two distinct awarenesses. It brings together what is not often so vividly brought together." He continues:

But at the same time it makes one aware, despite the juxtaposition, of the enormous distances between political efforts and actions needed to get things done and the rare flowerings of "Mozart moments." (3)

4 In another example, contemplating the adage "It is better to light a candle than to curse the darkness," he suggests that better than either alternative is suspending the call to action and contemplating the alternatives themselves. "But making the comparison, a meta-action, might itself be more satisfying than engaging in either action," he writes.

Comparisons do sway us, for better or worse, to move from action to contemplation, from deciding what to do to thinking about alternatives. Reflecting on a choice, to be sure, might help us to make a choice. But it gives us, inevitably, as a performance choice itself, another matter to reflect upon. It is a further hidden, and ongoing, move from the moral to the aesthetic, from the practical to the theoretical. (7)

He maintains that we regularly experience the collision of these two worlds and that the act of contrasting them is valuable. "If this book were to have a moral point," he tells us, "it would be to always remember [the] aesthetic alternative" (9).

6 After the Introduction the book divides into three sections. Part I, "Art and Morality," inquires into connections and tensions between the aesthetics of art and imperatives of morality. The first chapter, "Art and Morality" (1973), sets the stage for much of what follows. Grossman argues there is no absolute contrast between the business life and the enjoyment of art, despite their ostensibly different goals and background conditions. Life without art is condemned as "Movement without direction, process without contour, suffering without redemption" (22). On the other hand, to create or experience art devoid of relevance to life is to

[...] enjoy without reference to consequences, to be righteous without reference to

joy, to fiddle while Rome burns, and to raise flowers alongside the crematoria. (23)

7 The second essay, "Morality Bound and Unbound," carries these ideas over to a discussion about the moral obligations of both artist and audience. When an artist intends no social or political implications for her creation, the moral drama of the art (the drama of a play, for example) is called "bound"; art with a moral message or prescription is "unbound." Again, it is not only the distinction between types of artistic intent that interests Grossman; it is also the recognition of this distinction. "The tension between boundness and unboundness, their pull in opposite directions," he 
states, "is the ulterior drama of art. It is implicitly present in the experience of art" (30); and

[...] A searching and ongoing ambiguity with respect to boundness and unboundness is desirable [since] art enables us to elevate our vision from the drama of this or that specific issue to the larger drama of life itself, in which the temptations of art and the stirrings of morality are frozen in an unsettled condition of dynamic conflict. (31)

Grossman's musical talents add credence to his thoughts on the philosophy of music. "Music, Modulation, and Metaphor" (1980) is particularly fine. In it he attempts to "develop... an analogy between 'music motion' (i.e. modulation) and other kinds of travel, and seeks to show how the homing instinct animates both life and art." His analysis straddles "technical musical analysis" (though still accessible to the nonmusician) and "the phenomenological experience of music" (35). Like its sequel, "A Mozartian Recognition Scene," it should appeal to anyone interested in the philosophy of music.

The remaining essays in Part I further examine the spiritual and moral dimensions of art. In "A Note on Economy and Art," Grossman argues that

[...] Every instance of economy in art is a kind of parable of the economic situation of scarcity in life, and is aesthetically pleasing because of the deep echoes or urgency that are apparently awakened. (95)

In "An Aesthetic Glance at the Constitution," he trumpets the overlooked "style, intention, and performance" of a political document typically revered for its prescriptions. The moral import of the U.S. Constitution is important, but he argues that the

[...] Constitution is not without art. Looking at it aesthetically - creatively misreading it, taking the text for something other than it obviously is - can be a way of gaining unexpected insights. (98)

Similarly, in "Human Rights and Artistic Appreciations" (1979) he attempts an analogy between (1) the weighty business of justifying human rights and (2) engaging in art criticism. As he sees it, the two apparently distinct domains overlap since the articulation and defense of either involves drawing on "shared capacities, perceptions, responses, and attempts to gather them together in the formation of a communal appreciation or judgment" (112-3).

The middle set of essays, "Artistic Philosophers and Philosophical Artists," looks at the philosophical ideas of an eclectic mix of philosophers and writers, such as Peirce, Sartre, Lessing, and Lewis Carroll. In these essays, Grossman continues to invoke "neglected alternatives" and turn over perceived ambiguities. At times the exercise feels labored. For instance, in "Interpreting Peirce" (1985), Grossman asks whether the final paragraph of "The Fixation of Belief," in which Peirce (somewhat painfully) intones that a man's chosen logical method should be "loved and reverenced as his bride," is a passage intended as "deliberate, total irony," "partial irony," "no irony at all," or (oddly) "all of the above" (121). Grossman concludes with a note of ambiguity, commenting that scientific inquiry was Peirce's "tremulous lady and his immortal bride, neither and both" (126). Other essays are more compelling. In "How Sartre Must Be Read"(1968), he takes up the question of how can "the philosopher keep the mind's categories from impersonating and parading as nature's definitive structure?" (134). He looks to and finds answers in Sartre's 1948 essay "What Is Writing?." What he finds is 
an appealing "synthetic procedure" in Sartre's "making and undermining" of semiotic and ontological categorical distinctions (134).

The dialectical dilemmas Sartre gets into [he writes] are more than surmounted by his own larger awareness of these dilemmas and by the way he exhibits and overcomes them in subtle deliberateness of his juxtapositions. (142)

The remaining essays in Part II, "On Beardsley's 'An Aesthetic Definition of Art" (1983); "Lessing as Philosophical Dramatist: On Nathan the Wise" (undated); "Lewis Carroll: Pedophile and/or Platonist" (2005); and "Brancusi: Some Changing and Changeless Perspectives" (1976), also highlight perceived tensions and connections with the art/morality distinction. Grossman moves with impressive ease from discussing the poet-philosopher Gotthold Lessing (1729-1781) to an analysis of the aesthetics of perspective in the sculptures of Constantin Brancusi (1876-1957). His thought is often absorbing. In "Art and Death: A Sermon in the Form of an Essay" (1978), for example, he outlines an "aesthetic theory of death" - a dramatic treatment of the art/morality distinction.

The essays in Part III are on various ideas and themes that are prominent in Santayana's philosophy. In "Drama and Dialectic: Ways of Philosophizing"(1972), Grossman argues that although both expressive drama and logical dialectic are essential to philosophy,

[...] Too much attempted dramatic volume and variety can lead to irresolution, to will-lessness, to excessive chatter and ominous silence. But too much dialectical clarity can lead to tidiness at the price of largeness and to precision at the price of plenitude. (224)

He finds support for his view in Santayana's (neglected) book Dialogues in Limbo (1925), especially the dialogue "The Vortex of Dialectic." He explains how

[...] the choice between drama and dialectic is always with us. At any moment we can try to clarify what we've got, secure what we are, put up boundaries, milestones, and markers. This is the role of dialectic. But contrariwise we can try to extend our domains, become more than we have been, and venture into incertitude and conflict. This is the role of drama.

In Grossman's estimation, no "philosopher worthy of the name" will lose site of this distinction or bestow ultimate value on either drama or dialectic (227).

In “Ontology and Morality: Santayana on the 'Really Real”' (1980), Grossman argues that the perennial pursuit of an ultimate or highest form or reality (e.g. Plato's theory of Forms) should be finally abandoned. Grossman finds in Santayana's ontology of essence, matter, spirit, and truth, an alternative to pernicious ontological 'categorical summitry.' In his view, Santayana's distinction between the being of essences (ideal terms) and the existence of matter (physical things) avoids the pitfalls of rationalistic views of the universe and provides a more promising approach to ontology. Here his interpretation may be overly influenced by Buchler's notion of 'ontological parity.' Buchler's ontological parity is an uneasy fit with Santayana's ontology. Although Grossman is correct in asserting that Santayana did not place any special moral value on the realm essence or the realm of matter, he is incorrect to suggest, as he seems to do, that there is no 'primal' or logical order to the realms. Contrary to Buchler's ontological parity, all things are not 'equally real' in Santayana's ontology insofar as essences are eternal, matter is at most everlasting, and spirit and truth are logically dependent on each. As for prime moral value, a case could be made that this honor falls to spirit, since for Santayana it is the locus of all value. 

one has doubts, as I do, about his basic interpretation of Santayana's intentions and philosophical system. Grossman maintains, and he is not alone in his view, that Santayana was a supreme ironist who generated "wavering and drama" (244) as he semi-earnestly delineated a system of ontological categories. In chapters 19 and 20, "Spirited Spirituality" (1996) and "Interpreting Interpretations" (1989), he discusses Santayana's account of the spiritual life and style of philosophizing. Here his theory of Santayana as ironist comes to the fore. He finds Santayana having a philosophical reach exceeding his grasp; eschewing technical philosophy in favor of literature; and promoting paradoxes. For example, in the Sense of Beauty, Santayana notably defines 'beauty' as 'pleasure objectified.' Grossman argues that "the phrase 'pleasure objectified"'... is an oxymoron. Pleasure, or emotion, is subjective. What can be seen in its objective clarity is a term or an essence, which is not the same thing as having a human emotion... The only way to interpret the blatant contradiction of the phrase 'pleasure objectified' (as with the phrase 'spirited spirituality') is to see it as a depiction of an always imperfect process, a human happening that cannot be fully seized" (242). However this is not the only way to interpret Santayana's position. Another way is Humean: when we see an object we regard as beautiful, we 'gild and stain' the object with our sentiments. The words 'pleasure objectified' might be prima facie contradictory, but the notion of 'projecting values' is not obviously contradictory or ironic. Similarly, when Santayana uses the phrase 'living in the eternal,' Grossman argues that since it is practically impossible to 'live in the eternal' (we have to eat), Santayana "proclaimed" the phrase "living in the eternal" only "ironically" and rather intended to promote only "living in pursuit of the eternal" (244). But this critique is a straw man, a mixing-up of definitions, ideal ends, and practical realities. When Santayana discusses 'the spiritual life,' one need not see him as presenting a wholly unrealistic and therefore ironic philosophy. The spiritual life is an ideal, but it is not thereby ironic.

The remaining essays in the book, "Santayana's Aesthetics" (1992), "Santayana's The Last Puritan" (1995), "Santayana in California" (undated), and "Ultimate Santayana" (1992), also look at Santayana's philosophy from a "tension-filled" perspective of irony. Referring to Santayana's book on aesthetics, The Sense of Beauty, Grossman claims that "Santayana is cavalier about distinctions" (264) and that his treatment of aesthetics is "fundamentally critical, literary, and ironic" (265). Similarly, Santayana's novel is characterized as a "complicated interplay between biography and fiction, and in both directions it moves away from, and a recovery of, truth" (269); his comments on nature and the environment are said to "reveal the ongoing play of Santayana's contradictory or dramatic attitudes" (280). As for Santayana's life as a travelling scholar, Grossman contends that Santayana was a "stranger" to the different "physical and intellectual" worlds in which he lived and that "This profound and tension-filled double locus of his affiliations is the story of his life and work" (281).

Much of Grossman's writing is faithful to the letter and spirit Santayana's philosophy. His restatements of Santayana's ideas are often eloquent and he casts interesting sidelights on Santayana's views. He is a bit of a provocateur, challenging the reader to reconsider assumptions and arguments that might be taken for granted. However, his sense of irony can also feel one-dimensional: an "idée fixe" that he acknowledges in the book's introduction (14). Still, Grossman expounds his views on Santayana's 
philosophy, and his other chosen subjects, with clarity and conviction. He also invites the reader to see things in a particular way and with a spirit of free inquiry. For these reasons he successfully presents his essays "in the Spirit of George Santayana."

\section{AUTHORS}

\section{GLEN TILLER}

Texas A\&M University-Corpus Christi

glenn.tiller[at]tamucc.edu 